\title{
Flood Hazard Assessment in Madeira (Portugal) - The Case Study of Machico
}

\author{
Andrés Silva ${ }^{1}$, Leonardo Gonçalves ${ }^{1}$, André Moura ${ }^{1,2}$, Sérgio Lousada ${ }^{1,2,3,4,5}$, João Gouveia ${ }^{1}$, \\ Rafael Camacho ${ }^{1}$ \\ ${ }^{1}$ Faculty of Exact Sciences and Engineering (FCEE), Department of Civil Engineering and Geology (DECG), University of Madeira (UMa), \\ Funchal, Portugal \\ ${ }^{2}$ CITUR - Madeira - Centre for Tourism Research, Development and Innovation, Madeira, Portugal \\ ${ }^{3}$ VALORIZA - Research Centre for Endogenous Resource Valorization, Portalegre, Portugal \\ ${ }^{4}$ Environmental Resources Analysis Research Group (ARAM), University of Extremadura, Badajoz, Spain \\ ${ }^{5}$ Institute of Research on Territorial Governance and Inter-Organizational Cooperation, Dąbrowa Górnicza, Poland
}

Email address:

slousada@staff.uma.pt (S. Lousada)

\section{To cite this article:}

Andrés Silva, Leonardo Gonçalves, André Moura, Sérgio Lousada, João Gouveia, Rafael Camacho. Flood Hazard Assessment in Madeira (Portugal) - The Case Study of Machico. American Journal of Water Science and Engineering. Vol. 7, No. 1, 2021, pp. 1-13. doi: 10.11648/j.ajwse.20210701.11

Received: January 18, 2021; Accepted: January 27, 2021; Published: March 4, 2021

\begin{abstract}
This study aims to carry out a proper flood risk assessment in Machico's main watercourse and purpose at least two different flood mitigation measures to prevent major impacts over the watershed. Furthermore, the assessment addresses the need for structural-measures - i.e. detention basins - towards mitigating flood hazards under high-intensity and shortduration precipitation events. It became possible to morphometrically characterize all the watersheds using empirical equations to gather specific parameters and indexes. A proper articulation between the hydrological and the spatial analysis using geographic information systems was then carried out. According to many parameters calculated the watershed of Machico proved to assume a very large-size and to be highly prone to flash floods. The spatial analysis took into consideration the watershed's Fill Rate using both Dutch and the Ternary Phase Diagram methods and allowed us to define criteria towards the establishment of detention basins as a valid flood mitigation measure. Finally, it was clear that the watershed corresponding to Machico's main watercourse induces the need to further implement either a detention basin or to modify the roughness coefficient of its river channel. Moreover, the comparison between the results obtained with DROTA's Flood Risk Report, allows us to consider this study's outcome both satisfactory and valid.
\end{abstract}

Keywords: Flood Hazard, Hydraulics, Hydrology, Spatial Analysis, Territorial Management, Urban Planning

\section{Introduction}

Climate change has been a major issue and has contributed to the drastic increase of natural extreme phenomena - i.e., droughts and floods. Nowadays, flooding is considered as one of the most relevant hydrological risks since it endangers human settlement and causes a major impact on the socioeconomic activities of a city [1-6].

We can easily verify that cities that do not care about urban planning, and reveal an unmeasured urban area growth, become more exposed to extreme and destructive events [7]. The HANZE database has recorded approximately 1564 flooding events between 1870 and 2016, where 879 were classified as flash-floods, 606 as river floods, 56 related to coastal floods, and 23 to compound events. [8].

Floods are often defined as extreme hydrological events and can be categorized according to their temporal disposition or origin, whether it happens due to natural or human influence $[9,10]$.

Considering the growing urbanization index and climate change, flooding events have become critical problems that cities worldwide must face, particularly in tropical regions [1, $5,11]$. This happens mainly because of the impervious surface ratio's growth and, therefore, the increase of the 
surface runoff to drain all the rainfall into a river's mouth [12]. Besides all of this, in most of the cities that lack urban planning, there can be found roads that either cross or choke a river mouth's, thus becoming a key factor to the growing risk of harming people or damaging their goods [13].

Urban areas are at higher risk since they concentrate on a city's housing and commercial fabric $[14,15]$. Therefore, it is likely that because of urban growth, the number of extreme events with the risk of hurting people or causing damage to their properties and goods also increases $[8,16]$.

Contextually, it becomes necessary to perform a precise study that emphasizes all the parameters that contribute to an increased flood hazard - i.e., geomorphology, geology, hydrology, impervious surface index, slope, drainage density — in order further to establish flood hazard mitigation measures [17]. Even though we still do not have enough knowledge or the resources to eradicate this type of scenario and mostly avoid casualties, it is unquestionable that we are working towards achieving those goals [13]. Citizens need to be aware and start cooperating with local authorities and local government to properly manage and reduce the risk in flood-prone areas of a watershed like Machico's.

Urban drainage is considered the key factor in preventing or at least mitigate the problems caused by the aforementioned phenomena, that is, by rapidly direct the flow of a watershed towards its river mouth. Although it minimizes the risk of an overflow of the stream bed, it does not take any action over the problem's origin - the anthropogenic pressure that humans exercise over the watershed [18-20].

In this sense, a modern concept of urban drainage is now being established, also focusing on the environmental side of the solution by detaining or at least retarding the natural flow of a watershed, thus minimizing the effects of the anthropogenic pressure and restoring the hydrological condition of the basin [21]. This type of solution brings back to the table elder and simple ways of people detaining a specific amount of the rainfall of a watershed, commonly used back then with irrigation purposes - i.e., detention basins-, a structural flood mitigation measure particularly interesting in urban areas [20,21].
In summary, structural flood mitigation measures reveal themselves to solve the control of a watershed's flow rate [22]. Therefore, the present study aims to perform the local hydrological analysis, acting as a base point to solve the gaps in structural and non-structural measures already put into force in Madeira's Autonomous Region.

Finally, its major goals will assess the morphometrical features of Machico's main watercourse, thus enabling us to obtain all the data to apply in flood risk parametric methodologies and evaluate each parameter's relevance to define the watershed as flood-prone; to check whether it is necessary to design a detention basin as a structural measure towards flood mitigation; to analyse the possibility of modifying the roughness coefficient of the watercourse's streambed and walls as a structural solution.

Moreover, this study does not aim to obtain different results from the ones already published by the regional and national authorities for hydrological and spatial management. Instead, it aims to cooperate in the revaluation of that characterization of Madeira's watersheds, which completion period they expect by the end of 2021, whilst using other methodologies that will either validate or imply the need to reanalyse the authorities' results. Simultaneously, it is part of a project with its primary goal to classify each watershed regarding its flood risk to the population.

\section{Methodology}

\subsection{Study Area}

Regarding the watershed under study - Machico's main watercourse - , it is in Madeira's western municipality of Machico. Moreover, the Madeiran archipelago is a North Atlantic group of islands that integrates the Macaronesian Region between the latitudes $30^{\circ} 01^{\prime} \mathrm{N}$ and $33^{\circ} 08^{\prime} \mathrm{N}$ and between the longitudes $15^{\circ} 51^{\prime} \mathrm{W}$ and $17^{\circ} 30^{\prime} \mathrm{W}$ [23]. With an estimated total area of $796,77 \mathrm{~km}^{2}$, it is subdivided into four smaller islands, namely Madeira $\left(736,75 \mathrm{~km}^{2}\right)$, Figure 1; Porto Santo $\left(42,17 \mathrm{~km}^{2}\right)$; Desertas $\left(14,23 \mathrm{~km}^{2}\right)$ and Selvagens $\left(3,62 \mathrm{~km}^{2}\right)[24]$.

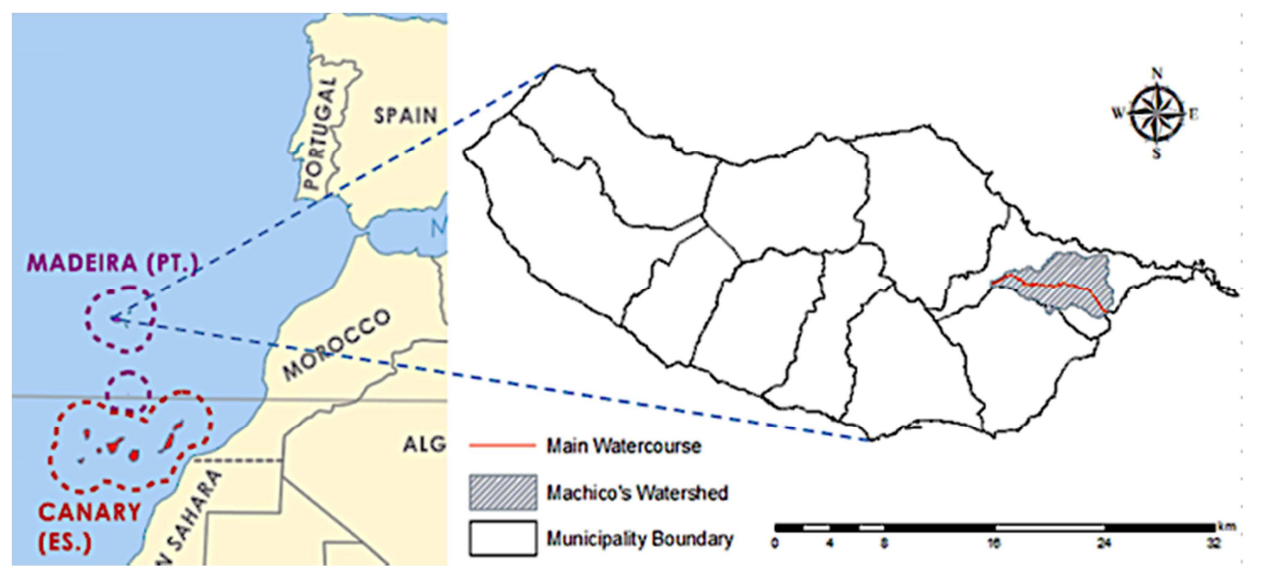

Figure 1. Macaronesian Region - Madeira Island and Machico's Watershed. (Source: Authors by ESRI ArcGIS, 2020). 


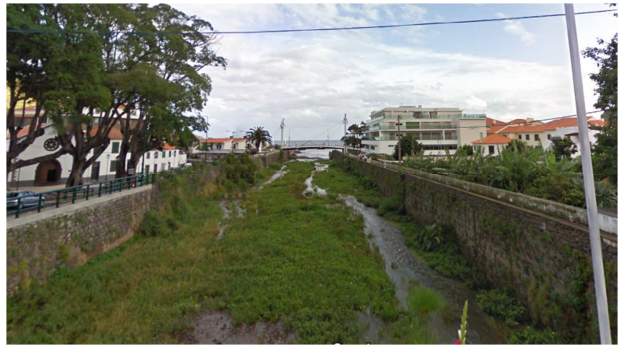

Figure 2. Conservation status of Machico's main watercourse river mouth.

conservation status of the considered watercourse is heterogeneous, with its river walls covered with both round and sharp stones and the streambed with excessive vegetation and full of sediments deposed over time, as seen in Figure 2.

The conservation status is approximately the same throughout the watercourse, this being a parameter easily verified in situ. Due to its tiny slope, the average flow rate is subsequently low, resulting in more sediment and organic matter deposition that promotes vegetation growth.

The adopted methodology can be synthesized into 6 main

The watershed of Machico has approximately 24,649 $\mathrm{km}^{2}$ stages/topics as shown in Figure 3.

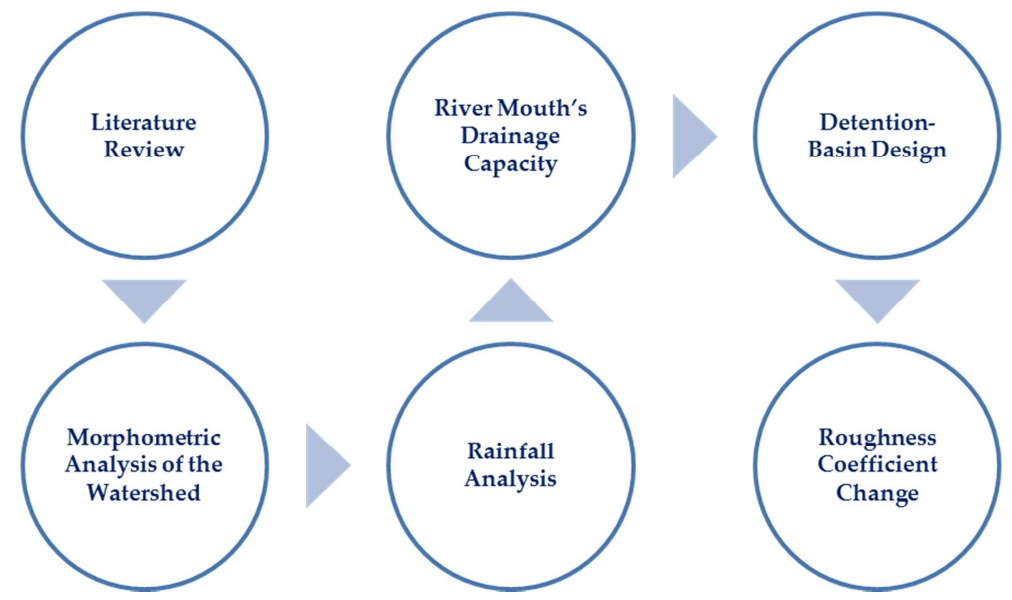

Figure 3. Adopted Methodology's Organogram.

The adopted methodology started with an extensive literature review to gather all the information needed to assess the morphometrical features of the Machico's watershed, taking into consideration the parameters (and the empirical equations) that many authors define as essential to consider a basin as flood-prone. The many stages of the adopted methodology shown in Figure 3 are described next.

\subsection{Morphometric Analysis of the Watershed}

The morphometric parameters include:

Gravelius compactness coefficient- $\mathrm{K}_{\mathrm{C}}$ : A dimensionless coefficient that establishes the ratio between a given watershed's perimeter and the perimeter of a perfectly round basin. It can be calculated using Equation 1, with the basin being flood-prone as the coefficient gets closer to 1 [25].

$$
\mathrm{K}_{\mathrm{C}}=\mathrm{P} / 2 \times \sqrt{\pi \times A}
$$

with:

\section{$\mathrm{P}=$ Watershed's perimeter, $\mathrm{km}$;}

$\mathrm{A}=$ Watershed's area, $\mathrm{km}^{2}$.

Elongation Factor- $\mathrm{K}_{\mathrm{L}}$ : A dimensionless coefficient that establishes the ratio between a given watershed's area and a rectangular-shaped watershed with the same area. It can be calculated using Equation 2, with the basing being considered elongated if the coefficient is bigger than 2 [6].

$$
\mathrm{K}_{\mathrm{L}}=\frac{\mathrm{L}_{\mathrm{E}}}{\mathrm{l}_{\mathrm{E}}}=\frac{\frac{\mathrm{K}_{\mathrm{C}} \times \sqrt{\mathrm{A}}}{1.128} \times\left|1+\sqrt{1-\left(\frac{1.128}{\mathrm{~K}_{\mathrm{C}}}\right)^{2}}\right|}{\frac{\mathrm{K}_{\mathrm{C}} \times \sqrt{\mathrm{A}}}{1.128} \times\left|1-\sqrt{1-\left(\frac{1.128}{\mathrm{~K}_{\mathrm{C}}}\right)^{2}}\right|}
$$

with:

$\mathrm{L}_{\mathrm{E}}=$ Equivalent length, km;

$\mathrm{l}_{\mathrm{E}}=$ Equivalent width, $\mathrm{km}$;

$\mathrm{K}_{\mathrm{C}}=$ Gravelius compactness coefficient, dimensionless;

$\mathrm{A}=$ Watershed's area, $\mathrm{km}^{2}$.

Form Factor $-\mathrm{K}_{\mathrm{F}}$ : A dimensionless coefficient that establishes the ratio between a given watershed's area and its length. It can be calculated using Equation 3, with the basing being considered elongated (and less flood-prone) as the Form Factor gets smaller [25, 26].

$$
\mathrm{K}_{\mathrm{F}}=\mathrm{A} / \mathrm{L}_{\mathrm{B}}^{2}
$$

with:

$\mathrm{A}=$ Watershed's area, $\mathrm{km}^{2}$;

$\mathrm{L}_{\mathrm{B}}=$ Watershed's length, km.

A watershed's length can be obtained by measuring the distance between its river mouth and the farthest point. It should be noted that the watershed's length does not necessarily correspond to its main watercourse length, thus being longer due to its high sinuosity. Therefore, it is extremely important to morphometrically characterize the 
watershed understudy.

Using the DEM (Digital Elevation Model) files kindly provided by LREC (Madeira's Civil Engineering Laboratory) and GIS-Software - ArcGIS — it was then possible to morphometrically characterize the Machico's main watercourse. The geomorphologic data that was gathered from this analysis was used in each author's empirical equation to avoid the single method's constraints.

As suggested by many authors, the morphometric analysis should have its origin in the establishment of a watercourse hierarchy - Strahler or Shreve - according to its order of magnitude [27]. These classifications are obtained by performing a hydrological analysis of the DEM file, getting both the "flow accumulation" and "flow direction" rasters, and using the "Stream Order" tool.

Strahler's watercourse hierarchy is often used as the first stage in other studies. In this one, it was useful to further analyse the planimetric and altimetric data of the considered watershed recurring to the ArcGIS Software.

The Strahler hierarchy is deeply associated with a watershed's ramification or bifurcation ratio, in which each degree of ramification or bifurcation can be calculated using Equation 4 [6, 25, 28-32].

$$
\mathrm{R}_{\mathrm{B}}=\frac{\mathrm{N}_{\mathrm{i}}}{\mathrm{N}_{\mathrm{i}+1}}
$$

with:

$\mathrm{N}_{\mathrm{i}}=$ Number of watercourses classified as " $\mathrm{i}$ "; dimensionless;

$\mathrm{N}_{\mathrm{i}+1}=$ Number of watercourses classified as “ $\mathrm{i}+1$ ", dimensionless.

A dimensionless coefficient that establishes the ratio between the number of watercourses of different classes. Moreover, the average bifurcation ratio can be calculated by using Equation 5.

$$
\overline{R_{B}}=\sqrt[i-1]{\prod_{i=1}^{i-1} \frac{N_{i}}{N_{i+1}}}=\sqrt[i-1]{N_{1}}
$$

with:

$\mathrm{N}_{\mathrm{i}}=$ Number of watercourses classified as " $\mathrm{i}$ "; dimensionless;
$\mathrm{N}_{\mathrm{i}+1}=$ Number of watercourses classified as “ $\mathrm{i}+1$ ", dimensionless;

$\mathrm{N}_{1}=$ Number of first-order watercourses.

Much like the previous parameter, the average bifurcation ratio is dimensionless as it simply represents an arithmetic mean of bifurcation ratios. Another key parameter that needs to be considered to characterize a watershed morphometrically is the time of concentration, meaning the time needed for all the watershed area to contribute towards the drainage of the rainfall. [20,33-35]. Bearing in mind that each author's empiric equation will lead to different times of concentration for the same watershed understudy, then was applied arithmetic mean to Kirpich (Equation 6), Témez (Equation 7), and Giandotti's (Equation 8) equations.

$$
\mathrm{t}_{\mathrm{C}}=57 \times\left(\mathrm{L}^{3} /\left(\mathrm{H}_{\mathrm{MAX}}-\mathrm{H}_{\mathrm{MIN}}\right)\right)^{0.385}
$$

with:

$\mathrm{t}_{\mathrm{C}}=$ Time of concentration, minutes;

$\mathrm{L}=$ Main watercourse's length, $\mathrm{km}$;

$\mathrm{H}_{\mathrm{MAX}}=$ Main watercourse's maximum height, m;

$\mathrm{H}_{\mathrm{MIN}}=$ Main watercourse's minimum height, $\mathrm{m}$.

$$
\mathrm{t}_{\mathrm{C}}=\left(\frac{\mathrm{L}}{\mathrm{i}^{0.25}}\right)^{0.76}
$$

with:

$\mathrm{t}_{\mathrm{C}}=$ Time of concentration, hours;

$\mathrm{L}=$ Main watercourse's length, $\mathrm{km}$;

$\mathrm{i}=$ Main watercourse's average slope, $\mathrm{m} / \mathrm{m}$.

$$
\mathrm{t}_{\mathrm{C}}=\frac{(4 \times \sqrt{\mathrm{A}})+(1.5 \times \mathrm{L})}{0.8 \times \sqrt{\mathrm{H}_{\mathrm{M}}}}
$$

$\mathrm{t}_{\mathrm{C}}=$ Time of concentration, hours;

$\mathrm{A}=$ Watershed's area, $\mathrm{km}^{2}$;

$\mathrm{L}=$ Main watercourse's length, km;

$\mathrm{H}_{\mathrm{M}}=$ Watershed's average height, $\mathrm{m}$.

\subsection{Rainfall Analysis}

The next step of the present study consisted of an extensive probabilistic analysis of extreme short-duration and high-intensity rainfall events of Machico's watershed, throughout the years. Contextually, the annual maximum daily rainfall was considered (based on the automatic rainfall stations' records) and then applied to Gumbel's probabilistic distribution resorting to Microsoft Excel's programmed spreadsheets. The annual maximum daily rainfall can be calculated using Equations 9, 10 and 11.

$$
\mathrm{P}_{\mathrm{EST}}=\mathrm{P}_{\mathrm{M}}+\mathrm{S}^{\prime} \times \mathrm{K}_{\mathrm{T}}
$$

with:

$\mathrm{P}_{\mathrm{EST}}=$ Annual maximum daily rainfall, $\mathrm{mm}$;

$\mathrm{P}_{\mathrm{M}}=$ Average annual rainfall, $\mathrm{mm}$;

$\mathrm{S}$ '=Sample's standard deviation, $\mathrm{mm}$;

$\mathrm{K}_{\mathrm{T}}=$ Frequency of occurrence, dimensionless. with:

$$
\mathrm{S}^{\prime}=\left(\frac{\sum\left(\mathrm{X}_{\mathrm{i}}-\mathrm{X}_{\mathrm{M}}\right)^{2}}{\mathrm{n} \prime}\right)^{0.5}
$$

with:

$\mathrm{X}_{\mathrm{i}}=$ Sample's value, $\mathrm{mm}$;

$\mathrm{X}_{\mathrm{M}}=$ Sample's average, $\mathrm{mm}$;

n'=number of samples.

$$
\mathrm{K}_{\mathrm{T}}=-\frac{6^{0.5}}{\pi} \cdot\left\{0.577216+\ln \left(\ln \left(\frac{\mathrm{T}_{\mathrm{R}}}{\mathrm{T}_{\mathrm{R}}-1}\right)\right)\right\}
$$

with:

$\mathrm{T}_{\mathrm{R}}=$ Return period, years.

After estimating the daily precipitation intensity of a particular rare-event, Equations 12 and 13 was used to calculate the intensity of the precipitation.

$$
\mathrm{I}=\frac{\mathrm{P}_{\mathrm{EST}} \times \mathrm{k}}{\mathrm{t}_{\mathrm{C}}}
$$


with:

$\mathrm{I}=$ Rainfall's intensity, $\mathrm{mm} / \mathrm{h}$;

$\mathrm{P}_{\mathrm{EST}}=$ Annual maximum daily rainfall, $\mathrm{mm}$;

$\mathrm{t}_{\mathrm{C}}=$ Time of concentration, hours;

$\mathrm{k}=$ Distribution coefficient, dimensionless. with:

$$
\mathrm{k}=0.181 \times \ln \left(\mathrm{t}_{\mathrm{C}}\right)+0.4368
$$

with:

$\mathrm{t}_{\mathrm{C}}=$ Time of concentration, hours.

The time distribution coefficient proves to be a keyparameter as the annual maximum daily rainfall is only valid for an extreme event that lasts 24 hours. Since the rainfall duration will eventually equal the time of concentration of the Machico's watershed, if we were to consider the total amount of rainfall on the hydrological analysis of the watercourse it would become too conservative and therefore the hydraulic infrastructures would be overdesigned [20].

\subsection{River Mouth's Drainage Capacity and Peak Flowrate}

Furthermore, the drainage capacity of the watershed's river mouth was calculated by using the Manning-Strickler's empirical equation (Equations 14 and 15) and compared to the expected flow rate of an extreme event with a 100-year return period. In order to estimate the expected flow rate of an extreme event with a 100-year return period, it was calculated using world-renowned author methodologies i.e., Forti (Equation 16); Pagliaro (Equation 17); Rational (Equation 18); Giandotti (Equation 19) and Mockus (Equation 20).

$$
Q_{M}=\left(\frac{1}{n}\right) \times A_{M} \times R^{\frac{2}{3}} \times \sqrt{i}
$$

with:

$\mathrm{Q}_{\mathrm{M}}=$ River mouth's drainage capacity, $\mathrm{m}^{3} / \mathrm{s}$.

$\mathrm{A}_{\mathrm{M}}=$ River mouth's section area, $\mathrm{m}^{2}$;

$\mathrm{R}=$ Hydraulic radius, $\mathrm{m}$;

$\mathrm{i}=$ River mouth's average slope, $\mathrm{m} / \mathrm{m}$;

$\mathrm{n}=$ River mouth's roughness coefficient, $\mathrm{m}^{-1 / 3} \mathrm{~s}$, Table 12 . with:

$$
R=\frac{B+2 \times h}{A_{M}}
$$

with:

B=River mouth's width, m;

$\mathrm{h}=$ River mouth's height, $\mathrm{m}$;

$\mathrm{A}_{\mathrm{M}}=$ River mouth's section area, $\mathrm{m}^{2}$;

In this case, it was necessary to use georeferencing systems to estimate the river mouth's section area.

$$
\mathrm{Q}_{\mathrm{Forti}}=\mathrm{A} \times\left(\mathrm{b} \times \frac{500}{125+\mathrm{A}}\right)+\mathrm{c}
$$

with:

$\mathrm{Q}_{\text {Forti }}=$ Forti's Peak flow rate, $\mathrm{m}^{3} / \mathrm{s}$;

$\mathrm{A}=$ Watershed's area, $\mathrm{km}^{2}$;

$\mathrm{b}=2,35$ for maximum daily rainfall intensity under $200 \mathrm{~mm}$ and 3,25 for maximum daily rainfall intensity over $200 \mathrm{~mm}$; $\mathrm{c}=0,5$ for maximum daily rainfall intensity under $200 \mathrm{~mm}$ for maximum daily rainfall intensity over $200 \mathrm{~mm}$.

$$
\mathrm{Q}_{\text {Pagliaro }}=\mathrm{A} \times\left(\frac{2900}{90 \times \mathrm{A}}\right)
$$

with:

$\mathrm{Q}_{\text {Pagliaro }}=$ Pagliaro's Peak flow rate, $\mathrm{m}^{3} / \mathrm{s}$;

$\mathrm{A}=$ Watershed's area, $\mathrm{km}^{2}$.

$$
\mathrm{Q}_{\text {Rational }}=\frac{\mathrm{C} \times \mathrm{I} \times \mathrm{A}}{3.6}
$$

with:

$\mathrm{Q}_{\text {Rational }}=$ Rational's Peak flow rate, $\mathrm{m}^{3} / \mathrm{s}$;

$\mathrm{C}=$ Surface runoff coefficient, Table 13;

$\mathrm{I}=$ Rainfall's intensity, $\mathrm{mm} / \mathrm{h}$;

$\mathrm{A}=$ Watershed's area, $\mathrm{km}^{2}$.

$$
\mathrm{Q}_{\text {Giandotti }}=\frac{\lambda \times \mathrm{A} \times \mathrm{P}_{\mathrm{MAX}}}{\mathrm{t}_{\mathrm{C}}}
$$

with:

$\mathrm{Q}_{\text {Giandotti }}=$ Giandotti's Peak flow rate, $\mathrm{m}^{3} / \mathrm{s}$; $\lambda=$ Reduction ratio, Table 14;

$\mathrm{A}=$ Watershed's area, $\mathrm{km}^{2}$;

$\mathrm{P}_{\mathrm{MAX}}=$ Rainfall's height for an event of equal duration and time of concentration, $\mathrm{mm}$;

$\mathrm{t}_{\mathrm{C}}=$ Time of concentration, hours.

$$
\mathrm{Q}_{\text {Mockus }}=\frac{2.08 \times \mathrm{A} \times \mathrm{P}_{\mathrm{EST}} \times \mathrm{C}}{\sqrt{\mathrm{t}_{\mathrm{C}}}+0.6 \times \mathrm{t}_{\mathrm{C}}}
$$

with:

$\mathrm{Q}_{\text {Mockus }}=$ Mockus' Peak flow rate, $\mathrm{m}^{3} / \mathrm{s}$;

$\mathrm{A}=$ Watershed's area, $\mathrm{km}^{2}$;

$\mathrm{P}_{\mathrm{EST}}=$ Annual maximum daily rainfall, $\mathrm{cm}$;

$\mathrm{C}=$ Surface runoff coefficient, Table 13;

$t_{C}=$ Time of concentration, hours.

As suggested, one of the main design criteria for detention basins - considering the safety of the population and their goods - is that the maximum flow rate must always remain under $85 \%$ of the watershed's drainage capacity [36]. Alternatively, this author also suggests that it should be designed a weir to maximize the watershed's drainage capacity in case a short-duration and high-intensity rainfall occurs, thus not allowing the watercourse to overflow.

Based on the aforementioned criteria, the Fill Rate must be calculated by using Equation 21, and in case the drainage capacity of the watershed proves to be insufficient a detention basin must be designed.

$$
\mathrm{FR}=\frac{\mathrm{Q}_{\mathrm{P}}}{\mathrm{Q}_{\mathrm{M}}} \times 100
$$

with:

$\mathrm{FR}=$ Fill Rate, \%;

$\mathrm{Q}_{\mathrm{P}}=$ Peak flow rates for each of the considered methodologies, $\mathrm{m}^{3} / \mathrm{s}$;

$\mathrm{Q}_{\mathrm{M}}=$ River mouth's drainage capacity, $\mathrm{m}^{3} / \mathrm{s}$.

The parameter Fill Rate is related to the river mouth's section area that is filled with rainfall. Therefore, when the FR gets over $100 \%$ it means that the watercourse can no 
longer contain the amount of rainfall and will necessarily overflow. Therefore, must be designed a detention basin that will act as a structural flood mitigation measure.

\subsection{Detention-Basin Design}

When the discharge capacity of a river mouth proves insufficient to remove all the stormwater flowing through a given catchment, it becomes necessary to construct a Cipolletti weir to throttle and control the flow, Equation 22. Once the flow capacity of the weir is set to an acceptable value, a detention basin can be designed based on the rainfall duration. Two main methods were used for this purpose, namely the Dutch (Equation 23) and the Ternary Phase Diagram - TPD (Equation 24).

$$
\mathrm{Q}_{\mathrm{S}}=1.86 \times \mathrm{L}_{\mathrm{SD}} \times \mathrm{H}_{\mathrm{D}}{ }^{1.5}
$$

with:

\section{$\mathrm{Q}_{\mathrm{s}}=$ Discharge rate, $\mathrm{m}^{3} / \mathrm{s}$;}

$\mathrm{L}_{\mathrm{SD}}=$ Weir's bottom width, $\mathrm{m}^{3} / \mathrm{s}$;

$\mathrm{H}_{\mathrm{D}}=$ Maximum height of water above the bottom of the weir, $\mathrm{m}$.

$$
V_{A}=\left(Q_{P}-Q_{S}\right) \times t_{C} \times 3600
$$

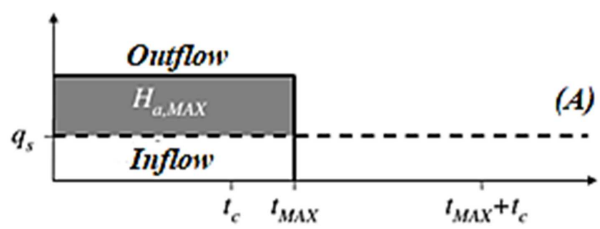

Figure 4. (A) Dutch Method; (B) TPD Method (Source: [37]).

It is observed that in the Dutch method storage begins immediately after precipitation, which is not the reality since storage starts only when the flow rate drained downstream of the watershed exceeds the drainage capacity of the weir.

\subsection{Modification of the Roughness Coefficient}

Moreover, a structural mitigation measure taken into consideration was changing the roughness coefficient of the walls and streambed of the watercourse, therefore avoiding the reduction of the drainage capacity due to friction. This methodology consists of changing the value of the parameter $\mathrm{n}$ in the Manning-Strickler equation, improving the flow rate of the given watercourse by considering another material for the river wall coverage.

\section{Results}

The results presented in this section are the result of applying the equations described in the previous section. Initially, to assess the morphometrical features of Machico's mains watercourse it was carried out an individual analysis of the parameters presented in Table 1, without correlating them, to evaluate the relevance of each of them to define the watershed as flood-prone.

$$
\mathrm{V}_{\mathrm{A}}=\frac{\left(\mathrm{Q}_{\mathrm{P}}-\mathrm{Q}_{\mathrm{S}}\right) \times\left(2 \times \mathrm{t}_{\mathrm{C}}-2 \times\left[\mathrm{Q}_{\mathrm{S}} /\left\{\mathrm{Q}_{\mathrm{P}} / \mathrm{t}_{\mathrm{C}}\right\}\right]\right)}{2}
$$

with:

$\mathrm{V}_{\mathrm{A}}=$ Retained flow, $\mathrm{m}^{3}$;

$\mathrm{Q}_{\mathrm{P}}=$ Rainfall flow rate, $\mathrm{m}^{3} / \mathrm{s}$;

$\mathrm{Q}_{\mathrm{s}}=$ Discharge rate, $\mathrm{m}^{3} / \mathrm{s}$;

$\mathrm{t}_{\mathrm{C}}=$ Time of concentration, hours.

The Equation 24 was formulated thanks to the geometric analysis of the Ternary Phase Diagram (Figure 7), taking into consideration that an event would last at least twice the time of concentration for the given watershed since a raindrop that would eventually fall over the watershed and specifically in its farthest place would need at least the time of concentration to reach the river mouth.

The main difference between both methodologies is because the Dutch method does not contemplate the delay and damping of the flood hydrogram, which leads to the overdesign of the structure [37], as displayed in Figure 4, with qs: Discharge rate; tc: time of concentration; tmáx: maximum duration (base); td: delay; $\mathrm{H}_{\mathrm{a}, \mathrm{MAX}}$ : Maximum storage capacity; i ( $\left.\mathrm{t}_{\mathrm{MAX}}\right)$ : Rainfall's intensity corresponding to the maximum duration.

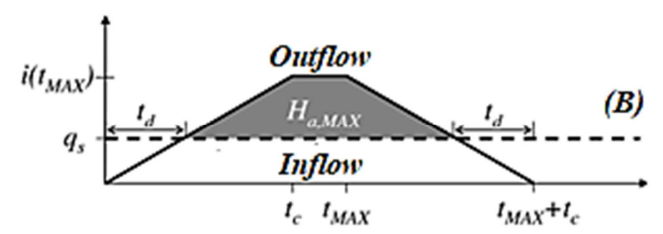

The first parameter to be studied refers to the area of the hydrographic basin, which has a primary role for the analysis of the volume of water flown to the mouth, where they can be classified as Very Large $>20 \mathrm{~km}^{2}$; Large $>10 \mathrm{~km}^{2}$; Average $>1 \mathrm{~km}^{2}$ and Small $<1 \mathrm{~km}^{2}$ [38]. Hence, as can be seen in the previous table, the river basin under study has a "Very Large" classification, which also suggests a greater propensity for floods concerning smaller hydrographic basins. It is notorious that the dimension analysis parameter is arbitrary and may differ according to the type of analysis to be performed [38], as well as the propensity to floods.

Table 1. Parameters Calculated or Extracted from ArcGIS.

\begin{tabular}{ll}
\hline Parameter & Value \\
\hline Area $\left(\mathrm{km}^{2}\right)$ & 24.649 \\
Perimeter $(\mathrm{km})$ & 34.700 \\
Main watercourse length (km) & 12.071 \\
Maximum Altitude of the Main Watercourse (m) & 984.999 \\
Minimum Altitude of the Main Watercourse (m) & 0.000 \\
Average Concentration Time (hours) & 2.249 \\
Gravelius compactness coefficient (dimensionless) & 1.972 \\
Elongation Factor (dimensionless) & 10.122 \\
Form Factor (dimensionless) & 0.311 \\
Number of Watercourses (units) & 833.000 \\
Average bifurcation ratio (dimensionless) & 5.169 \\
Strahler classification (dimensionless) & 5.000 \\
\hline
\end{tabular}


Because of the moderate variation of the elongation and hypsometry of this watershed shown in Figure 5, meaning that the ratio between the watershed's altitude and length is not too high, therefore the watershed does not reveal itself to be flood-prone.

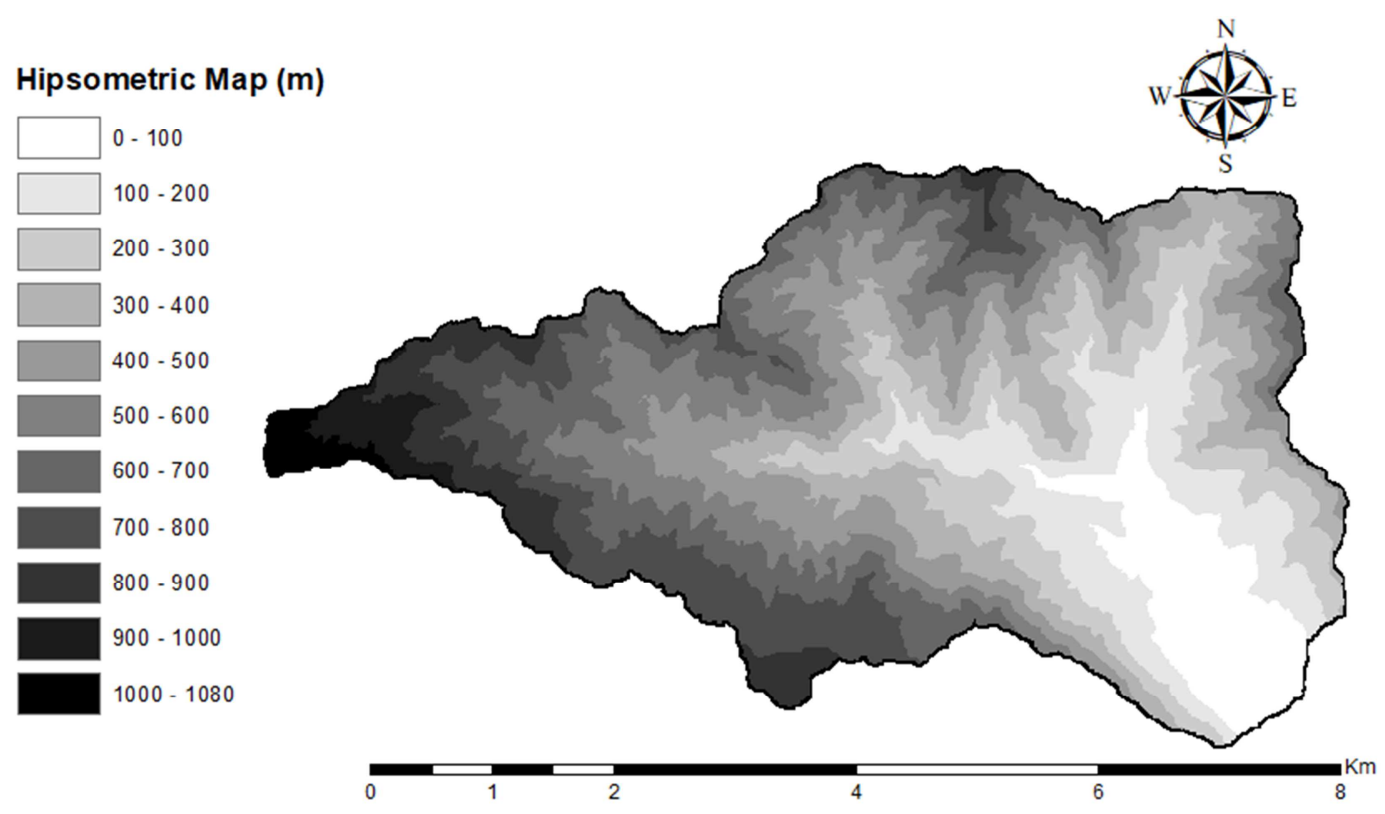

Figure 5. Machico's Hydrographic Basin-DEM File (Source: Authors by ESRI Arc GIS, 2020).

Finally, concerning the drainage network of the watershed, as shown in Figure 6, the number of watercourses suggests a high drainage capacity-i.e., the ratio between the number of watercourses and the basin's area), and subsequently a higher predisposition to floods.

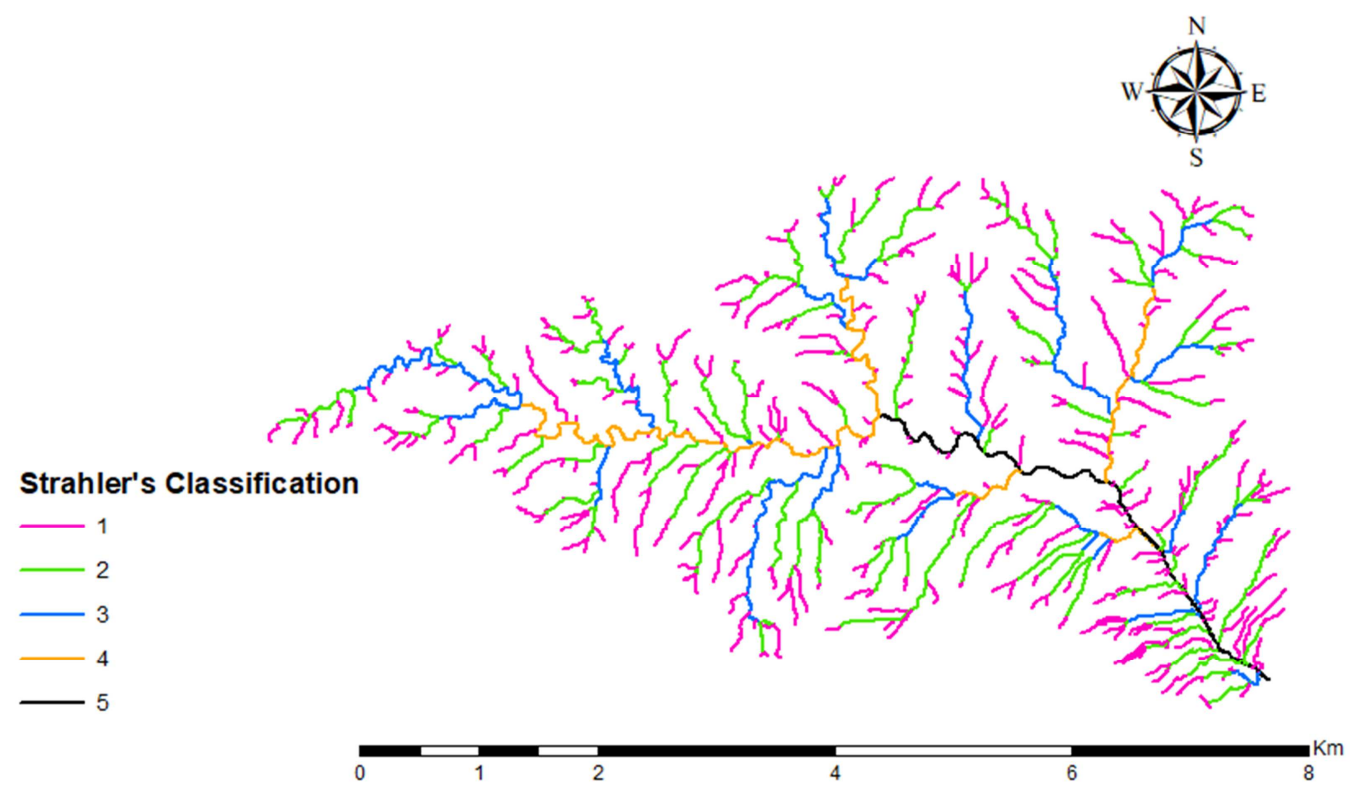

Figure 6. Strahler's Classification (Source: Authors by ESRI ArcGIS, 2020).

For the rainfall analysis, the data provided by the National Water Resources Information System (SNIRH) were used with sample data for sixteen years, presented in Table 15 and Figure 8. In the probabilistic treatment of the Gumbel's Distribution, the values presented in Table 2 were obtained.

With the determination of the expected precipitation intensity for a recurrence time of 100 years and using the methodologies previously explained, the peak flow rates of full, presented in Table 3. It is evident that the surface flow coefficient used in the Rational Method corresponds to the value of 0.700 (Table 4 ), that is, it was considered a region with a considerable urban index where $70 \%$ of the precipitate volume will be directed to the mouth through surface flow since the area under study is characterized as a commercial region, presented in the Table 13. 
Table 2. Rainfall parameters.

\begin{tabular}{lll}
\hline Parameter & Symbol & Value \\
\hline Average Annual Rainfall $(\mathrm{mm})$ & $\mathrm{P}_{\mathrm{M}}$ & 112.025 \\
Standard Deviation $(\mathrm{mm})$ & $\mathrm{S}^{\prime}$ & 53.844 \\
Frequency Factor & $\mathrm{K}_{\mathrm{T}}$ & 3.136 \\
Time Breakdown Coefficient & $\mathrm{k}$ & 0.259 \\
Annual Maximum Daily Rainfall $(\mathrm{mm})$ & $\mathrm{P}_{\mathrm{EST}}$ & 280.916 \\
Precipitation Intensity $(\mathrm{mm} / \mathrm{h})$ & $\mathrm{I}$ & 72.883 \\
\hline
\end{tabular}

Table 3. Peak Flow Rates.

\begin{tabular}{ll}
\hline Methodology & Flow Rate $\left(\mathbf{m}^{3} / \mathbf{s}\right)$ \\
\hline Forti & 292.306 \\
Pagliaro & 623.486 \\
Rational & 379.424 \\
Giandotti & 280.141 \\
Mockus & 379.090 \\
\hline
\end{tabular}

Table 4. Adopted Surface Runoff Coefficient (Source: [39]).

\begin{tabular}{lll}
\hline Urban Areas & & \\
\hline Land Occupation & & Surface Runoff Coefficient \\
\hline \multirow{2}{*}{ Commercial Areas } & City district & $0.700-0.950$ \\
& Periphery & $0.500-0.700$ \\
\hline
\end{tabular}

Table 5. Adopted Giandotti's Reduction Coefficient (Source: [40]).

\begin{tabular}{lll}
\hline $\mathbf{A}\left(\mathbf{k m}^{\mathbf{2}}\right)$ & $\boldsymbol{\lambda}$ & "C" Equivalent \\
\hline$<300$ & 0.346 & 1.250 \\
\hline
\end{tabular}

It was used the value of $\lambda$ presented in Table 5 to calculate Giandotti's flowrate.

Table 6. Assessment of the Need for Implementing a Detention Basin.

\begin{tabular}{ll}
\hline Parameter & Value \\
\hline River's Mouth Width (m) & 24.000 \\
River's Mouth Height (m) & 3.000 \\
River's Mouth Flow Rate Capacity $\left(\mathrm{m}^{3} / \mathrm{s}\right)$ & 358.512 \\
Pre-measured Fill Rate (\%) - Forti & 82 \\
Pre-measured Fill Rate (\%)-Pagliaro & 174 \\
Pre-measured Fill Rate (\%) - Rational & 106 \\
Pre-measured Fill Rate (\%)-Giandotti & 78 \\
Pre-measured Fill Rate (\%) - Mockus & 106 \\
\hline
\end{tabular}

Subsequently, the analysis of the flow capacity of the estuary through the equation Manning-Strickler and the verification of the need to implement a detention basin was carried out, obtaining the values shown in Table 6 . Since the walls and the riverbed are covered by different materials and consequently have different roughness coefficients, the weighted average was taken for this parameter, with the walls consisting of mortared stone masonry in good condition $(n=0.020)$ and the bed consisting of a rocky canal vegetated in poor condition $(n=0.040)$. A slope of $0.01 \mathrm{~m} / \mathrm{m}$ was assumed to account for a similar gradient to that at the mouth of the river, where it reaches a minimum and critical value due to the low gradient.

Examination of Table 6 shows that the fill rate is above the established limit of $85 \%$ for the methods of Pagliaro, Rational, and Mockus and that the installation of flood control measures is imperative. Since the discharge capacity of the estuary was found to be insufficient, a detention basin was designed to control the discharge of the Machico catchment, considering the spatial disposition and all the infrastructures in the surrounding area.

First, the Cipolletti's weir was sized to regulate runoff and drain the estuary within its discharge limits. The characteristics of the Cipolletti's weir are shown in Table 7.

Table 7. Application of Cipolletti's Weir.

\begin{tabular}{ll}
\hline Parameter & Value \\
\hline Width of the Weir Sill $(\mathrm{m})$ & 22.000 \\
Head on Weir Crest (m) & 3.000 \\
Weir's Exit Water Flow Rate $\left(\mathrm{m}^{3} / \mathrm{s}\right)$ & 212.627 \\
Post-measured Fill Rate $(\%)$ - Pagliaro & 59 \\
Post-measured Fill Rate (\%) - Rational & 59 \\
Post-measured Fill Rate (\%) - Mockus & 59 \\
\hline
\end{tabular}

Thereafter, detention basins were designed using the Dutch and TPD methods. It is important to emphasize that both methods have a simplified character, as they tend to neglect several factors and features and may represent oversizing. Another pivotal aspect of this design procedure refers to the possibility of keeping the height and width of the stream to reduce the environmental and urban impacts due to the implementation works of the measure. Therefore, the only geometric variable of the detention basin will be its length, so the length of the basin must be smaller than the total length of the main watercourse (calculation criterion). After performing the calculations, the values presented in Table 8 were obtained.

Table 8. Design of the Detention Basin.

\begin{tabular}{ll}
\hline Parameter & Value \\
\hline Width of Detention Basin (m) & 24.000 \\
Detention Basin Height (m) & 3.000 \\
Length of Detention Basin (m)-Dutch Method (Pagliaro) & 46209.209 \\
Length of Detention Basin (m)-TPD Method (Pagliaro) & 30450.512 \\
Length of Detention Basin (m)-Dutch Method (Rational) & 18759.575 \\
Length of Detention Basin (m)-TPD Method (Rational) & 8246.862 \\
Length of Detention Basin (m)-Dutch Method (Mockus) & 18722.056 \\
Length of the Detention Basin (m)-TPD Method (Mockus) & 8221.105 \\
\hline
\end{tabular}

Finally, the modification of the roughness coefficient was studied as another structural flood mitigation measure, whilst maintaining the streambed's vegetation characteristics. Thus, the values presented in Table 9 correspond more precisely to the improvement of the state of conservation of the stream, towards reducing the loss of flow capacity caused by excessive friction between the fluid and the coating material.

Table 9. Modification in the Roughness Coefficient.

\begin{tabular}{ll}
\hline Parameter & Value \\
\hline Roughness Coefficient of the Walls - Modified & 0.012 \\
Bed Roughness Coefficient - Modified & 0.030 \\
River's Mouth Flow Capacity - Modified $\left(\mathrm{m}^{3} / \mathrm{s}\right)$ & 488.881 \\
Fill Rate-Post-Modified (\%) - Pagliaro & 128 \\
Fill Rate-Post-Modified (\%) - Rational & 78 \\
Fill Rate-Post-Modified (\%) - Mockus & 78 \\
\hline
\end{tabular}

The modified roughness coefficients of the walls correspond to a surface with cement mortar in good condition, while in the stream's bed to a stony bed vegetated in good condition, as presented in Table 10. 


\section{Discussion}

Since the primary purpose of this research was the recommendation of a simplified measure for mitigating the impacts of downstream floods, the structural design of the holding basin for the Machico's Watershed proved to be effective in controlling the flow rate at the outfall, where the fill rate value went from $174 \%, 106 \%$, and $106 \%$, for the Methodologies of Pagliaro, Rational and Mockus, respectively, to $59 \%$ - i.e., below the pre-established limit. As the values obtained to confirm the flood risk analysis carried out by the leading regional authority (DROTA), it is considered that there is acceptable accuracy in this study, Table 11.

Table 10. Adopted Manning-Strickler Roughness Coefficient (Source: [40]).

\begin{tabular}{|c|c|c|c|c|}
\hline Type of channel and description & Very Good & Good & Regular & Bad \\
\hline Channels with stony bed and vegetated slope & 0.025 & 0.030 & 0.035 & 0.040 \\
\hline Cement mortar surfaces & 0.011 & 0.012 & 0.013 & 0.015 \\
\hline
\end{tabular}

Table 11. Watersheds with Significant Flood Risk. (Source: [42]).

\begin{tabular}{ll}
\hline Municipality & Watershed \\
\hline \multirow{3}{*}{ Machico } & Ribeira de Machico \\
& Ribeira do Junçal \\
& Ribeira da Maiata \\
\hline
\end{tabular}

It is patent that the proposal of this research aims to origin the least possible impact on the existing waterway and its surroundings. In this sense, it was decided not to alter the dimensions of the cross-section of the streams, both in width and in height. Furthermore, the only dimensional variant of the holding basin was its length. Based on this assumption, the Dutch method presented considerable oversizing, as the total length of the holding basin found must be larger than the full length of the mainstream, which denotes the need to change one more of the flow sections, particularly height or width. Consequently, despite the efficiency in the flow rate regularization, the Dutch method did not apply to the urban conditions previously imposed. Therefore, after substantiating the non-applicability of this methodology in this specific case, the TPD method was adopted.

Concerning the TPD method, the same conditions were imposed, notwithstanding, the methodology showed applicability, considering that the total length of the holding basin is smaller than the full length of the main watercourse, except for the peak flow rate calculated by the Pagliaro method, which presented a very dissimilar value of the other methodologies.

Considering the alteration in the roughness coefficient of the stream, it was decided to remain with the characteristic of vegetation in the stream bed, since the complete removal of the vegetation cover would have to be very frequent. Even so, it is considered that the stream bed remains in good condition and with less dense vegetation than it is currently. Regarding the walls, maintenance should not be constant since abrasion wear would occur solely with the presence of considerable volumes of water with sediments of significant granulometry.

The modification of the roughness coefficient in the channels was a successful measure to mitigate the effects of the floods, where the Fill Rate is established within the previously addressed criterion-i.e. the precipitate flow corresponds to less than $85 \%$ of the mouth flow capacity. It is highlighted that both methodologies are applicable-i.e. TPD method and the modification of the roughness coefficientcan be employed together to shorten the length of the holding basin by optimizing the mouth flow capacity.
As aforementioned, the methodologies used are simplified in nature, that is, they do not consider local particularities. As an outcome, the measures tend to possess too high a safety margin, resulting in oversizing of the hydraulic structures in question. Induced by the impossibility of exploring all aspects that compose a more accomplished and effective analysis in this academic exercise, other studies can be carried out with the purpose to complement or optimize the results obtained here, such as analysis of soil infiltration capacity; analysis of the flow capacity of the implemented urban hydraulic system aiming to reduce the storage volume of the holding basins; sediment deposition analysis; verification of the deterioration of the canal walls by abrasion; analysis from the perspective of urban growth and its influence on the increase in flow, among others.

\section{Conclusions}

The results of this study show that the catchment area of the main watercourse of Machico is at risk of flooding, which is confirmed by DROTA's Flood Risk Report. Although one of the streams has a considerable width, its depth is relatively shallow, and the presence of vegetation in the streambed makes the discharge capacity of its estuary insufficient when compared to the expected discharge determined by the methods of Pagliaro, Rational, and Mockus.

Also, the Dutch Method could not be considered as an active measure to reduce or even prevent flooding impacts because the length of the detention basin obtained by using this method was much greater than the actual length of the watercourse. In contrast, the length of the detention basin obtained by the many methods of Ternary Phase Diagram is shorter than the actual length of the watercourse, which proves that it is a valid option and that it is not necessary to increase its width. The only exception was Pagliaro's method, where the determined flow was higher than the average, leading to an oversizing of the infrastructure itself.

Finally, changing the roughness coefficient of the channel proved to be a pragmatic yet very effective way of mitigating 
the effects of flash floods by increasing the discharge capacity of the estuary and then reducing the degree of filling to $85 \%$ (as recommended).

This study allowed us to characterize another watershed in
Madeira and will undoubtedly be an important contribution to the project of classifying each hydrographic basin of the island, taking into account the risk of flooding and the resulting impact on people's lives.

\section{Appendix}

Table 12. Manning-Strickler Roughness Coefficient (Source: [40]).

\begin{tabular}{|c|c|c|c|c|}
\hline Type of channel and description & Very Good & Good & Regular & Bad \\
\hline Mortared stone masonry & 0.017 & 0.020 & 0.025 & 0.030 \\
\hline Rigged stone masonry & 0.013 & 0.014 & 0.015 & 0.017 \\
\hline Dry stone masonry & 0.025 & 0.033 & 0.033 & 0.035 \\
\hline Brick masonry & 0.012 & 0.013 & 0.015 & 0.017 \\
\hline Smooth metal gutters (semicircular) & 0.011 & 0.012 & 0.013 & 0.016 \\
\hline Open channels in rock (irregular) & 0.035 & 0.040 & 0.045 & - \\
\hline Channels with bottom on land and slope with stones & 0.028 & 0.030 & 0.033 & 0.035 \\
\hline Channels with stony bed and vegetated slope & 0.025 & 0.030 & 0.035 & 0.040 \\
\hline Channels with concrete coating & 0.012 & 0.014 & 0.016 & 0.018 \\
\hline Earth channels (rectilinear and uniform) & 0.017 & 0.020 & 0.023 & 0.025 \\
\hline Dredged canals & 0.025 & 0.028 & 0.030 & 0.033 \\
\hline Clay conduits (drainage) & 0.011 & 0.012 & 0.014 & 0.017 \\
\hline Vitrified clay conduits (sewage) & 0.011 & 0.013 & 0.015 & 0.017 \\
\hline Flattened wooden plank conduits & 0.010 & 0.012 & 0.013 & 0.014 \\
\hline Gabion & 0.022 & 0.030 & 0.035 & - \\
\hline Cement mortar surfaces & 0.011 & 0.012 & 0.013 & 0.015 \\
\hline Smoothed cement surfaces & 0.010 & 0.011 & 0.012 & 0.013 \\
\hline Cast iron coated tube with tar & 0.011 & 0.012 & 0.013 & - \\
\hline Uncoated cast iron pipe & 0.012 & 0.013 & 0.014 & 0.015 \\
\hline Brass or glass tubes & 0.009 & 0.010 & 0.012 & 0.013 \\
\hline Concrete pipes & 0.012 & 0.013 & 0.015 & 0.016 \\
\hline Galvanized iron pipes & 0.013 & 0.014 & 0.015 & 0.017 \\
\hline Rectilinear and uniform clean streams and rivers & 0.025 & 0.028 & 0.030 & 0.033 \\
\hline Streams and rivers cleared rectilinear and uniform with stones and vegetation & 0.030 & 0.033 & 0.035 & 0.040 \\
\hline Streams and rivers cleared rectilinear and uniform with intricacies and wells & 0.035 & 0.040 & 0.045 & 0.050 \\
\hline Spread margins with little vegetation & 0.050 & 0.060 & 0.070 & 0.080 \\
\hline Spread margins with lots of vegetation & 0.075 & 0.100 & 0.125 & 0.150 \\
\hline
\end{tabular}

Table 13. Surface Runoff Coefficients (Source: [39]).

\begin{tabular}{lll}
\hline Urban Areas & & \\
\hline Land Occupation & Surface Runoff Coefficient \\
\hline & Lawns in sandy soils & $0.050-0.200$ \\
Green Areas & Lawns on heavy soils & $0.150-0.350$ \\
& Parks and cemeteries & $0.100-0.350$ \\
& Sports fields & $0.200-0.350$ \\
Commercial Areas & City district & $0.700-0.950$ \\
& Periphery & $0.500-0.700$ \\
Residential Areas & Town-center villas & $0.300-0.500$ \\
& Villas on the outskirts & $0.250-0.400$ \\
Industrial Areas & Apartment buildings & $0.500-0.700$ \\
Railways & Dispersed industry & $0.500-0.800$ \\
& Concentrated industry & $0.600-0.900$ \\
Streets and Roads & & $0.200-0.400$ \\
& Paved & $0.700-0.900$ \\
\hline
\end{tabular}

Table 14. Giandotti Reduction Coefficients (Source: [40]).

\begin{tabular}{lll}
\hline $\mathbf{A}\left(\mathbf{k m}^{\mathbf{2}}\right)$ & $\boldsymbol{\lambda}$ & "C" Equivalent \\
\hline$<300$ & 0.346 & 1.250 \\
$300-500$ & 0.277 & 1.000 \\
$500-1000$ & 0.197 & 0.710 \\
$1000-8000$ & 0.100 & 0.360 \\
$8000-20000$ & 0.076 & 0.270 \\
$20000-70000$ & 0.055 & 0.200 \\
\hline
\end{tabular}


Table 15. Precipitation Historical Data (Source: [41]).

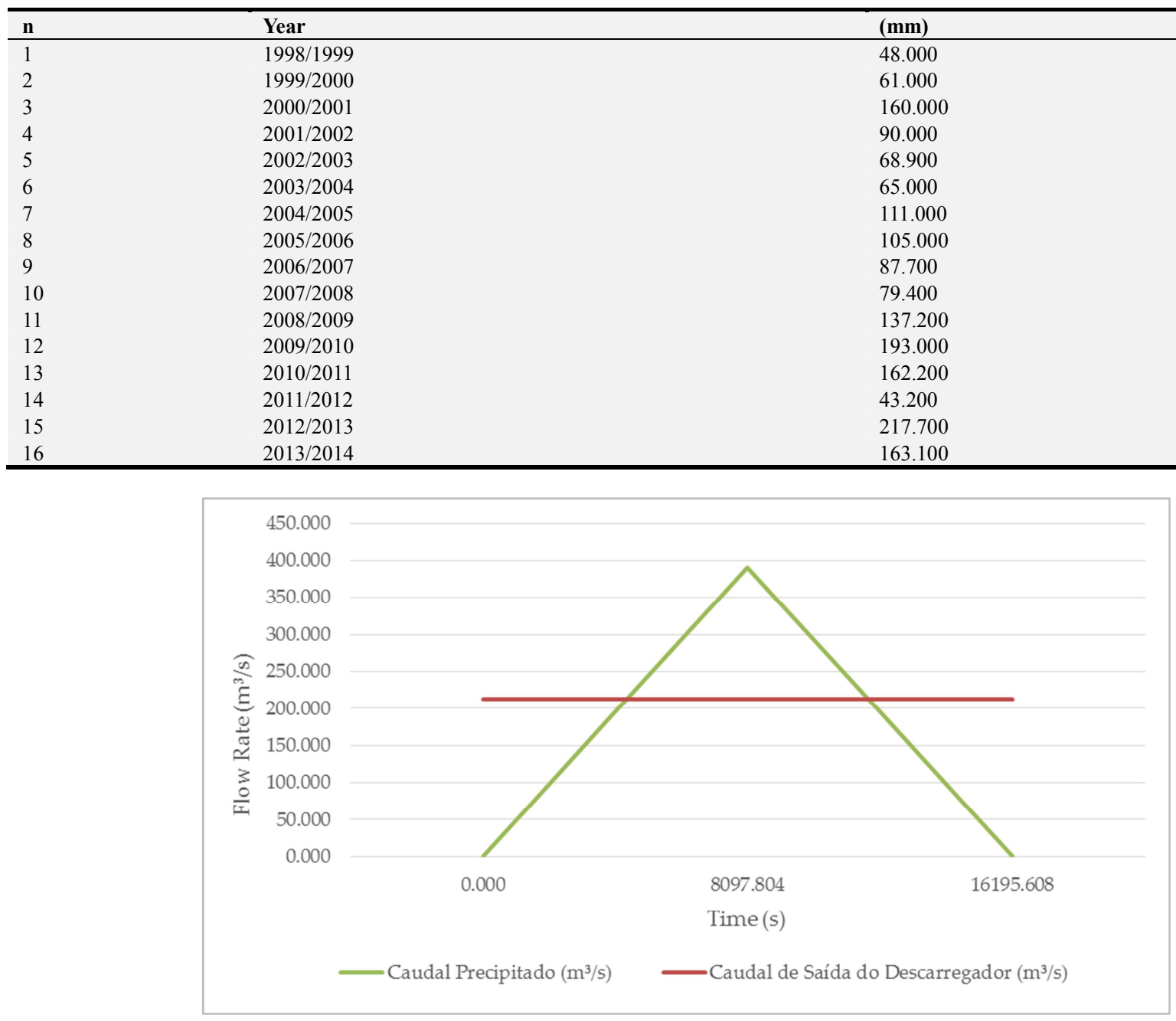

Figure 7. Ternary Phase Diagram.

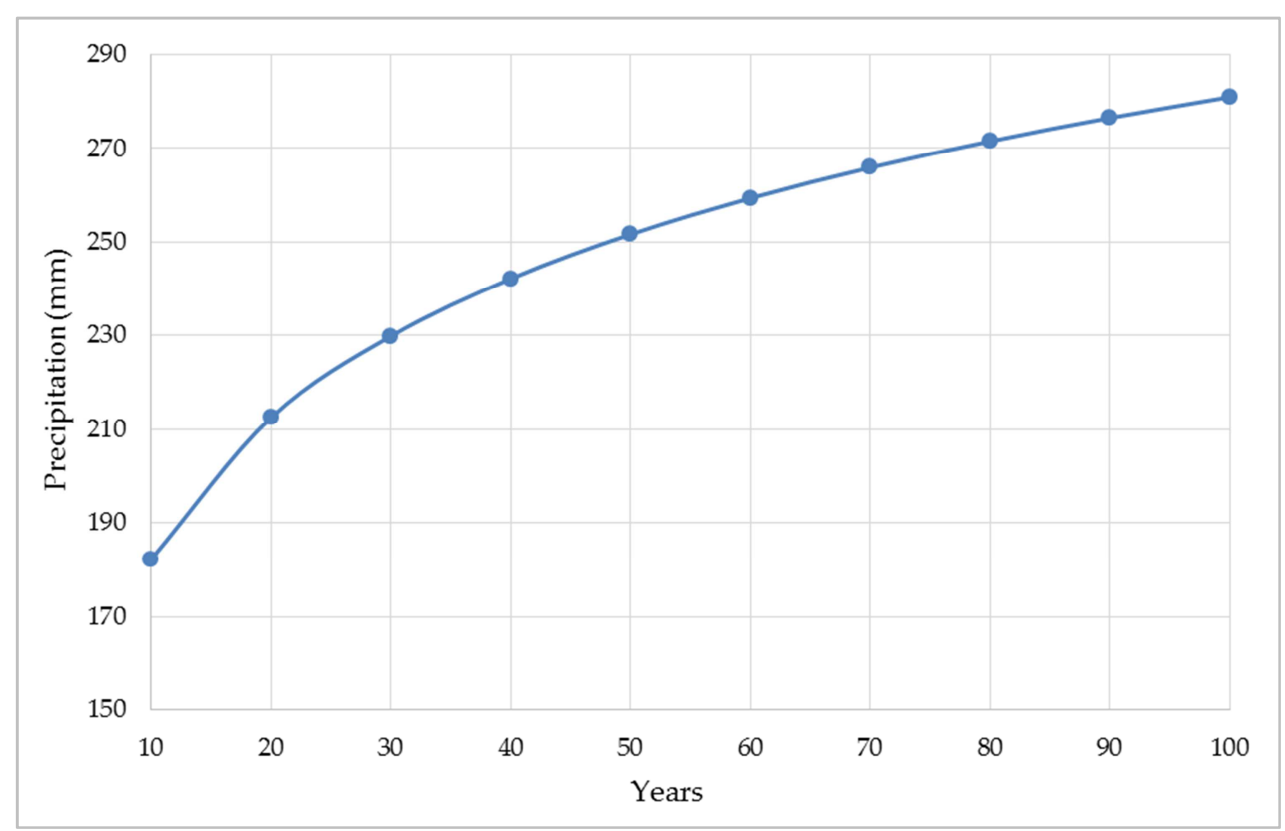

Figure 8. Expected Rainfall for Machico's Watershed. 


\section{References}

[1] Tucci, C. E. M. (1993). Controle de Enchentes. Hidrologia: Ciência e Aplicação. $2^{\mathrm{a}}$ Edição. Editora da Universidade UFRGS.

[2] Franco, E.; Fill, H. (2004). Dimensionamento de bacias de detenção das águas pluviais com base no método racional. 2004. 155 f. Dissertação (Mestrado) - Curso de Programa de Pós-graduação em Engenharia de Recursos Hídricos e Ambiental, Universidade Federal do Paraná, Curitiba, 2004.

[3] Borrego, C.; Lopes, M.; Ribeiro, I.; Carvalho, A. (2009). As alterações climáticas: uma realidade transformada em desafio. Revista Debater a Europa, No 1, junho/dezembro, 15-40.

[4] Moreira, A.; Ramos, M. (2016). Alterações climáticas e suas consequências: deslocamentos populacionais forçados. The Overarching Issues of the European Space. Rethinking Socioeconomic and Environmental Problems, Porto. pp. 203-219.

[5] Gonçalves, L. B.; Lousada, S. A. N.; Cabezas, J. (2019). Análise teórico-prática da precisão dos descarregadores retangulares e triangulares: Otimização das simulações à escala para os caudais em bacias de detenção. Livro de Resumos, Universidade de Évora, Novembro de 2019. ISBN: 978-972-778-134-8.

[6] Camacho, R. F. (2015). Caractererização, Simulação (à escala) e Modelação do Escoamento em Canais Artificiais. Aplicação a caso de estudo. Dissertação para obtenção do grau de Mestre em Engenharia Civil pela Universidade da Madeira, Funchal, Portugal.

[7] Freitas, M.; Andrade, C. (2007). Alterações Climáticas e Impactos na Linha de Costa. XXIX Curso de Actualização de Professores em Geociências (pp. 35-43). Escola Superior de Educação de Lisboa.

[8] Paprotny, D.; Sebastian, A.; Morales-Nápoles, O.; Jonkman, S. N. (2018). Trends in flood losses in Europe over the past 150 years. Nature Communications. DOI: 10.1038/s41467-01804253-1.

[9] Chow, V. T. (1956). Hydrologic Studies of Floods in the United States. Inter. Assoc. Sci. Hydrol., Publ. n 42, 134-170.

[10] Guedes, L. J. S. (2014). Riscos de Cheias e inundações. Estudo de um caso: Esposende. Trabalho escrito no âmbito da disciplina da UC de Geologia Ambiental, Lic. Em GeologiaUMinho, 2014/2015. Universidade do Minho.

[11] Barichivichi, J.; Gloor, E.; Peylin, P; Brienen, R.; Schöngart, J.; Espinoza, J.; Pattnayak, K. (2018). Recent intensification of Amazon flooding extremes driven by strengthened Walker circulation. Science Advances: eaat8785.

[12] Canholi, A. (2005). Drenagem Urbana e Controle de Enchentes. São Paulo: Oficina de Textos.

[13] Caetano, C. (2014). Avaliação do risco de aluviões das ribeiras da ilha da Madeira. Dissertação elaborada para a obtenção do grau de Mestre em Engenharia do Ambiente pelo Instituto Técnico de Lisboa, Lisboa.

[14] Hough, M. (1998). Naturaleza y ciudad: Planificación urbana y procesos ecológicos. Barcelona: Gustavo Gilli.
[15] Silva, C. S.; Santiago, A. (2007). Urbanização e Inundação: Conflitos e Possibilidades. Paisagem Ambiente: Ensaios n. 24-São Paulo. pp. 327-334.

[16] Campana, N. A.; Tucci, C. E. M. (1994). Estimativa de área impermeável de microbacias urbanas. Caderno de Recursos Hídricos, v. 12, n. 2, p. 79-94.

[17] Warner, K.; Hamza, M.; Oliver-Smith, A.; Renaud/, F.; Julca, A. (2008). Climate change, environmental degradation and migration. Nat Hazards, 55 (3), 689-715.

[18] Tucci, C. E. M.; Porto, R. L.; Barros, M. T. (1995). Drenagem Urbana. Universidade Federal do Rio Grande do Sul (UFRGS), $414 p$.

[19] Parkinson, J.; Milograna, J.; Campos, L. C.; Campos, R. (2003). Drenagem urbana sustentável no Brasil. Goiânia: Universidade Federal de Goiás, Loughborough University, 2003. (Relatório do workshop de 7 de maio de 2003).

[20] Gonçalves, L. B.; Lousada, S. A. N. (2020). Análise Probabilística de Cheias e o Uso de Bacias de Detenção como Medida Mitigadora: Aplicação à Bacia de Santa Luzia. Revista Científica Monfragüe Desarrollo Resiliente, Volumen XIII, ISSN: 2340-5457.

[21] Nakazone, L. M.; Porto, R. L. L (2005). Implantação de reservatórios de detenção em conjuntos habitacionais: a experiência da CDHU. Dissertação elaborada para obtenção do grau de Mestre em Engenharia Civil pela Escola Politécnica, Universidade de São Paulo, São Paulo.

[22] Reis, J. J. S. (2015). Estruturas de Correção Torrencial nas Ribeiras do Funchal-Açudes. Inventariação e análise comparativa. Dissertação de Mestrado em Engenharia Civil. Faculdade de Ciências Exatas e da Engenharia - Universidade da Madeira, Funchal.

[23] Fernandes, M. J. P. (2009). Riscos no Concelho da Ribeira Brava: Movimentos de vertente cheias rápidas e inundações. Dissertação para obtenção do grau de Mestre em Dinâmicas Sociais e Riscos Naturais pela Universidade de Coimbra.

[24] Prada, S.; Gaspar, A.; Sequeira, M. M.; Nunes, A. (2005). Disponibilidades Hídricas na Ilha da Madeira. In Book: AQUAMAC-Técnicas e métodos para a gestão sustentável da água na Macaronésia, Chapter: Disponibilidades Hídricas na Ilha da Madeira, Publisher: Instituto Tecnológico das Canarias, Cabildo de Lanzarote, Consejo Insular de Aguas de Lanzarote, Editors: Instituto Tecnológico de Canarias, pp. 261-294.

[25] Lousada, S. A. N. \& Camacho, R. (2018). Hidrologia, recursos hídricos e ambiente - Aulas Teóricas. Vol. I, ISBN 978-9898805-33-1, Universidade da Madeira. 230 p.

[26] Ferreira, C. W. \& Lima, C. S. \& Cavalcanti, L. C. S. \& Santos, A. H. O. (2010). Caracterização morfométrica da bacia hidrográfica do açude Cachoeira II, no município de Serra Talhada-PE, Brasil. VI Seminário Latino Americano de Geografia Física. Universidade de Coimbra.

[27] Christofoletti, A. (1980). Geomorfologia. São Paulo: Edgard Blücher.

[28] Strahler A. N. (1964). Quantitative geomorphology of drainage basins and channel networks. Section 4-II, in Chow, Ven Te; Maidment, D. R; Mays, L. W. (1988). Applied Hydrology, McGraw-Hill, New York. 
[29] Chow, V. T. (1988). Applied Hydrology. McGraw-Hill Series in Water Resources and Environmental Engineering. Chow, V. T.; Maidment, D. R.; Mays, L. W., IV Series. ISBN: 0 07010810-2.

[30] Silveira, A. L.; Louzada, J. A.; Beltrame, L. (1993). Infiltração e Armazenamento no Solo. Hidrologia: Ciência e Aplicação. $2^{\text {a }}$ Edição. Editora da Universidade UFRGS.

[31] Guimarães, R. C. (2017). Capítulo 2 - Bacia Hidrográfica. In: Guimarães, R. C., Shahidian, S. e Rodrigues, C. M. (Editores). Hidrologia Agrícola, 2a edição. ISBN: 978-989-8550-40-8. ECT e ICAAM. Évora, 5-22.

[32] Moura, A. D. S. (2019). Canais Artificiais e a sua Influência em Processos de Planeamento Urbano e Ordenamento Territorial. Dissertação para obtenção do grau de Mestre em Engenharia Civil pela Universidade da Madeira.

[33] Villela, S. M. \& Mattos, A. (1975). Hidrologia Aplicada. Editora Mc Graw Hill, São Paulo. 245p.

[34] Martins, M. F.; Candido, G. A. (2012). Indicadores de Desenvolvimento Sustentável para Localidades: uma proposta metodológica de construção e análise. Revista de Gestão Social e Ambiental. ISSN: 1981-982X. DOI: 10.5773/rgsa.v6i1.229.

[35] Justi Junior, J. \& Andreoli, C. V. (2015). Uso de dados climáticos e hidrológicos como subsídio na determinação do regime de fluxo de canais de drenagem. Revista Brasileira de Geomorfologia. Vol. 16, n. 1. ISSN: 2236-5664.

[36] Porto, R. L. \& Filho, K. Z. \& Tucci, C. E. M. \& Bidone, F.
(1993). Drenagem Urbana. Hidrologia: Ciência e Aplicação. $2^{\mathrm{a}}$ Edição. Editora da Universidade UFRGS.

[37] David, L. M. \& Carvalho, R. F. (2008). Bacias de Retenção para Controlo de Cheias: Reflexão sobre os métodos de dimensionamento. $13^{\circ}$ Encontro Nacional de Saneamento Básico.

[38] Beck, H. E.; Bruijnzeel, L. A.; Van Dijk, A. I. J. M.; McVicar, T. R.; Scatena, F. N.; Schellekens, J. (2013). The impact of forest regeneration on streamflow in 12 mesoscale humid tropical catchments. Hydrol. Earth Syst. Sci., 17, 2613-2635, 2013. DOI: 10.5194/hess-17-2613-2013.

[39] Chow, V. (1964). Handbook of Applied Hydrology. New York: McGraw-Hill.

[40] Gonçalves, J. (2016). Caracterização do coeficiente de rugosidade e seu efeito no escoamento em Canais Naturais. Simulação e Modelação (à escala) no laboratório de Hidráulica. Aplicação às ribeiras do Funchal. Dissertação para obtenção do grau de Mestre em Engenharia Civil pela Universidade da Madeira, Funchal, Portugal.

[41] SNIRH (2020). Sistema Nacional de Informação de Recursos Hídricos. Disponível em: https://snirh.apambiente.pt/index.php?idMain=2\&idItem=1\&o bjCover=920123704\&objSite=920685506; Acesso em: 20 de Junho de 2020.

[42] DROTA (2017). Identificação das Zonas Críticas a Cartografar Considerando os Impactos da Ocorrência de Inundações (Com Risco Potencial Significativo). Direção Regional de Ordenamento do Território e Ambiente. 